\title{
A Cost-Based Approach to Elicit Ancillary Service Tariffs from Unified Capacity and Energy Tariffs
}

\author{
Hikmet Sezer, Ali Nezih Güven, Osman Bülent Tör, Mahmut Erkut Cebeci, and Saeed Teimourzadeh
}

\begin{abstract}
Establishing separated markets for capacity, energy, and ancillary services (AS) is one of the key steps to liberalize electricity sector and realize electricity markets. This study aims at eliciting AS tariffs from unified capacity and energy tariffs through a cost-based approach. In the proposed framework, maintaining annual revenue requirements of the power plants is considered as the main objective while separating the AS tariff from unified tariffs. The conducted study considers two types of unified tariffs, i.e., capacity and energy tariffs, and offers proper AS eliciting scheme for each type of unified tariffs. The main challenges addressed here are: 1) incentivizing/penalizing AS provision morelless than scheduled amount which is tackled through an incentive factor, and 2) preventing overall tariff increment (customer tariff) after eliciting AS tariff which is addressed by applying fixing constraint to the overall tariff at before and after AS tariff eliciting conditions. Last but not the least, AS trade between adjacent utilities and calculating the benefits from this trade are addressed. The effectiveness of the proposed methodology is assured through numerical investigations.
\end{abstract}

Index Terms-Ancillary Service, Balancing Market, Frequency Regulation, Capacity Tariff, Energy Tariff.

\section{INTRODUCTION}

A NCILLARY SERVICES and balancing facilities are countermeasures to ensure nodal power balances when

HIKMET SEZER is with Çalık Enerji, Istanbul, Turkey, (e-mail: hikmet.sezer@yesilirmakedas.com).

(iD) https://orcid.org/0000-0002-3628-7619

ALI NEZIH GÜVEN is with Middle East Technical University, Ankara, Turkey, (e-mail: guven@metu.edu.tr).

(D) https://orcid.org/0000-0001-6041-7199

OSMAN BÜLENT TÖR, is with EPRA Electric Energy Co., Ankara, Turkey (e-mail: osman.tor@epra.com.tr).

(iD https://orcid.org/0000-0002-7634-2475

MAHMUT ERKUT CEBECI is with EPRA Electric Energy Co., Ankara, Turkey (e-mail: erkut.cebeci@epra.com.tr).

(iD) https://orcid.org/0000-0003-2519-0309

SAEED TEIMOURZADEH is with EPRA Electric Energy Co., Ankara, Turkey (e-mail: saeed@epra.com.tr).

(iD) https://orcid.org/0000-0001-8295-8404

Manuscript received April 1, 2020; accepted Jan 30, 2022.

DOI: $10.17694 /$ bajece.711158 the system operation parameters are violated from prescheduled condition [1]-[3]. Day-ahead scheduling and market clearance identify the committed generation units, determine associated operating points and allocate required reserves for the next operating day. Meanwhile, power system operator must ensure that sufficient resources are available, given any variation in system operation conditions from the day-ahead schedules, and power plants are dispatched on a moment-tomoment basis maintaining system balance and security [4]-[6].

To maintain the generationlconsumption balance, the power system operator needs the ability of calling on identified generation assets or demand-side assets. AS is the service offered or facilitated by the power system operators for power quality procurement and system balancing purposes which allows multiple users to utilize the transmission network while preserving system security. The power system operators keep on hand to meet unexpected imbalances between prescheduled and actual load and generation. Balancing energy is the actual deployment of this capacity realized through setaside reserve capacity which might be procured from market participants or neighbouring systems [7]. In other words, balancing services means either or both balancing capacity and balancing energy.

The language used to describe ancillary service, balancing facilities and imbalance notions is not always consistent across localities. One of the important aspects of the European Union (EU) Internal Energy Market (IEM) is to harmonize network operating practices, including how to define ancillary service and balancing facilities and imbalance notions [8]. "Balancing" is a process, while AS are diverse products to be defined and supplied for balancing. Balancing and AS are often discussed together because they are core functions for secure operation of power system. Some AS are part of the balancing function itself and designed to ensure continuous balancing of the power system. Other AS, say voltage (or reactive power) regulation, black start, are necessary for grid operation and security, but not necessarily for the balancing process [9]. This study addresses balancing aspects of AS which focuses on active power (MW) regulation capability (ramp up/down) of power plants.

This study addresses separation of AS tariffs from uniform capacity and energy tariffs for vertically integrated utilities (VIU) which are starting electricity market liberations and implementing uniform tariffs for power plants. Georgia, 
Armenia and Black Sea region countries are among the countries which are at transition from VIU to liberalized electricity markets. Unified tariffs are implemented in many utilities round-the-globe, particularly in developing countries, to cover annual revenue requirements (ARR) of the power plants [10]. Eliciting AS tariffs from unified tariffs is among the most important duties of energy market regulatory authorities in these VIU as a critical step towards liberalizing electricity market opening. By the separated AS tariffs in place, 1) the true cost levels of providing AS can be identified; 2) Obeying to/violating from the pre-scheduled AS can be remunerated/penalized; 3) AS trade between the adjacent utilities can be initiated. However, the discussed benefits are in challenge with concerns such as how to incentivise AS providers; and how to prevent overall tariff increment (customer tariff) after eliciting AS tariff (see Fig. 1).

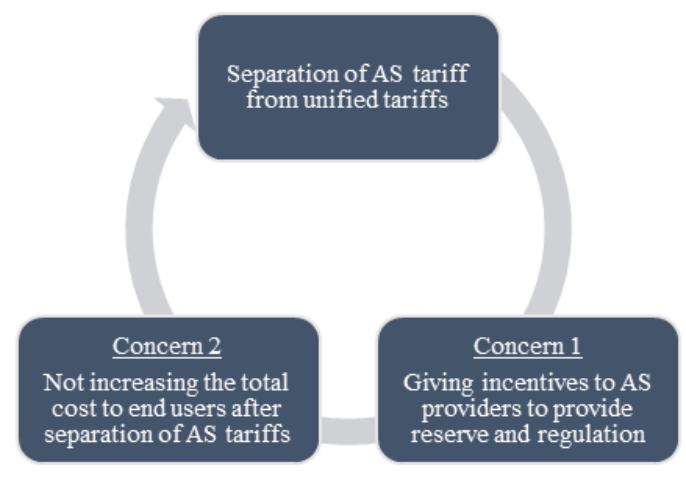

Fig.1. Concerns for separating AS tariffs from unified tariffs

Unified capacity tariffs (UCT) already include remuneration for providing AS independent from amount of AS provision. In other words, under unified tariff mechanisms, there is no motivation for the power plants to provide AS unless a penalty mechanism is introduced for the cases that the power plant refuse to provide AS. Under such a circumstance, the obvious solution is to separate the AS tariffs from the uniform tariffs and remunerate provision of AS through a separate AS tariffs mechanism. This is also required to calculate the benefits of utilities attained from coupling their ancillary service and balancing facilities services with other utilities through interconnection lines. Quantification of coupled AS provision, such as exchanging of spinning reserves between two countries, cannot be made properly unless AS tariff is separately calculated. Here, relevant studies in the literature are generally based on cost-based or market-based assumptions [11]. By separating AS tariff, those power plants who have enjoyed the remuneration of AS provision through unified tariffs will definitely be unwilling to adopt separated AS tariffs. The main reason is that such power plants will be remunerated - if and only if they provide AS satisfactorily. Therefore, an incentive mechanism should be considered in case of separated AS tariff methodology [12]. Nevertheless, such incentive mechanism should not result a significant increase in total payments to power plants as illustrated in Figure 1. Otherwise, it will be difficult for the energy market regulatory authorities to explain the tariff increment to the end-users.

In a competitive AS market environment, price of AS provision is determined by the competition among the AS providers (referred as "market-based" approach) [13], [14]. Although it is aimed to procure AS through such market-based approaches, "cost-based" approaches are inevitable particularly at the initial phase of market opening [15]. In the cost-based approaches, price of a commodity is determined commonly based on either "marginal-based" or "pay-as-bid" mechanisms [16]. In "pay-as-bid" mechanisms, cost-based approaches should consider a profit component in determining ARRs of the power plants [17]. Profit component in pay-asbid mechanisms is more critical than that of marginal-based mechanisms given that the market clearing at marginal price already provides a room for profit of power plants unless they are marginal.

Unified capacity and energy tariffs of power plants are generally determined annually using cost-based approaches [18]. Each year, power plants provide associated costs (fixed and variable) to energy market regulatory authorities. Afterwards, the ARRs for power plants are settled after some negotiations between the power plants and energy market regulatory authorities. ARRs are encompasses fixed costs (i.e., costs which are independent of power generation amount), variable costs (costs associated with power generation amount), depreciation costs, and profit component [19]. It is worth mentioning that cost-based approaches are also being utilized in developed markets when a market power/abuse is observed [18]. In such a case, energy market regulatory authorities identify the price based on cost-based approaches. Hence, separated AS tariffing is not an interim solution until market opening indeed and can be used in case of liberalized electricity market.

This paper offers a cost-based approach to elicit the AS tariffs from the unified tariffs. In the proposed framework, maintaining annual revenue requirements of the power plants are considered as the main objective while separating the AS tariff from unified tariffs. The conducted study considers two types of unified tariffs, i.e., capacity and energy tariffs, and offers proper AS eliciting scheme for each type of unified tariffs. The main challenges addressed here are: 1) incentivizinglpenalizing AS provision morelless than scheduled amount which is tackled through an incentive factor, and 2) preventing overall tariff increment (customer tariff) after eliciting AS tariff which is addressed by applying fixing constraint to the overall tariff at before and after AS tariff eliciting conditions [20]. Last but not the least, AS trade between adjacent utilities and calculating the benefits from this trade are addressed. The proposed approach is tested through numerical analysis for generic power plants. Fixed and variable cost parameters of the generic power plants are given in [19], [21].

\section{Proposed Methodology}

In this section, first, the proposed methodologies for eliciting AS tariff from capacity and energy tariffs are presented. Next, the proposed scheme for AS trade between 
adjacent utilities and calculating the benefits of this trade is presented. The following assumptions are made in separating AS tariffs from unified tariffs:

- AS tariff is constant for two different type of spinning reserves: 1) Primary reserves, (frequency containment reserve FCR); and 2) Secondary reserves (frequency restoration reserve; FRR) [22]. In other words, there is a single AS tariff both for FCR and FRR. However, provision of FCR and FRR are remunerated separetely, based on the allocated reserve amount as illustrated in Fig. 2.

- AS providers are assumed to allocate spinning reserves based on power system operator requirements which are responsible from identifying total amount of spinning reserve requirements in term of FCR and FRR, separately.

- AS tariff is symmetrical in terms of upward and downward activation of FCR and FRR. For instance, if a power plant is allocated for providing $10 \% \mathrm{FCR}$, associated upper level for dispatch can be $90 \%$ of its capacity.

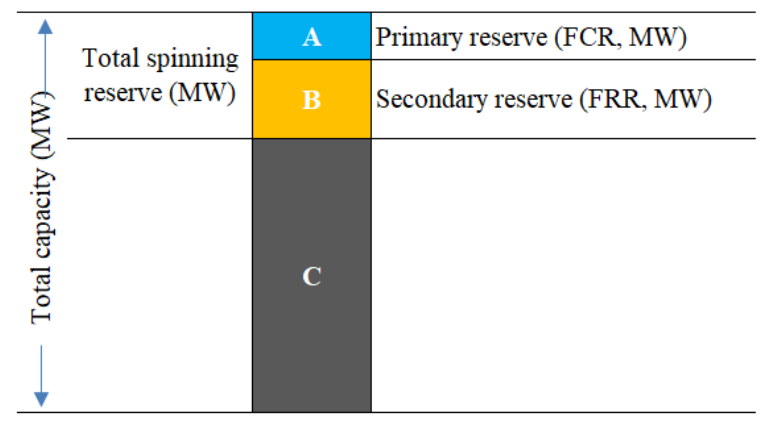

Fig.2. Spinning reserve concept in the proposed AS tariff mechanism

- Settling time is assumed to be one hour. That is, ancillary service tariff is in $\$ / M W / h$.

- No separate capacity tariff for tertiary reserves (i.e., replacement reserve, $\mathrm{RR}$ ) and RRs are procured from the balancing market.

- It is assumed that upward and downward activation of FCR cancel each other gradually, as illustrated in Fig. 3. Therefore, there is no additional remuneration for the energy generated during the activation of FCR in the upward direction.

- In contrast to FCR, the amount of energy activated to provide FRR in both upward and downward directions, is subjected to balancing market. That is, the net energy balance of the AS providers should be remunerated in the balancing market, as illustrated in Fig. 3.

Figure 3 presents chronological activation of FCR, FRR, and RR after losing a generation unit in a typical power grid. Subsequent to this event, the frequency immediately starts decreasing (alteration $\# 1$ in Fig. 3). Here, the generationldemand balance is tried to be recovered through activating FCR in upward direction (\#2). The frequency is restored to the pre-disturbance level by activating the FRR (\#3) and RR (\#6) in upward direction, respectively. This process ensures restoration of the FCR and FRR (downward activation) to their initial values as well. Although deployment of unified energy tariffs $(\$ / \mathrm{MWh})$ is a common practice, some countries implement capacity tariffs $(\$ / \mathrm{MW} / \mathrm{h})$ in addition to energy tariffs. Capacity tariff mechanisms are generally implemented to mitigate security and reliability concerns [18]. In economics, variable costs and fixed costs are the two main costs a company has when producing goods and services. A variable cost varies with the amount produced, while a fixed cost remains fix independent from the output. It is common to determine capacity tariffs with respect to the fixed-cost driven ARR of the power plants.

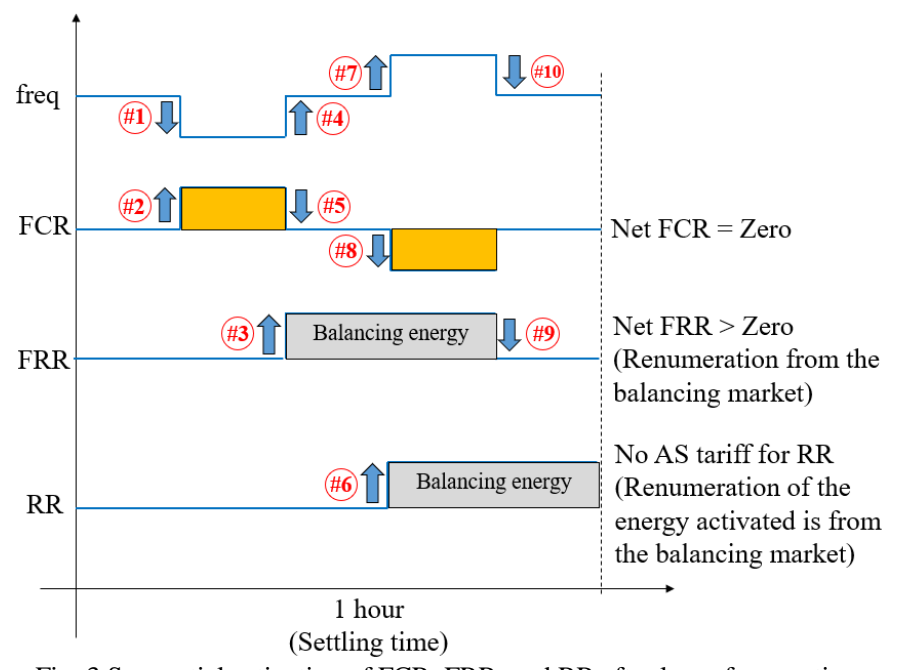

Fig. 3 Sequential activation of FCR, FRR, and RR after loss of generation.

Given the above-discussed assumptions, the proposed methodologies for eliciting AS tariff from unfied energy and capacity tariff are addressed in the following:

\section{A. Eliciting AS Tariff from Unified Capacity Tariff (UCT)}

Eliciting AS tariff from UCT $(\$ / M W / h)$ is investigated in this section. The proposed methodology is based on fixedcosts driven ARR of the power plants. Figure 4 depicts the outline of the proposed approach.

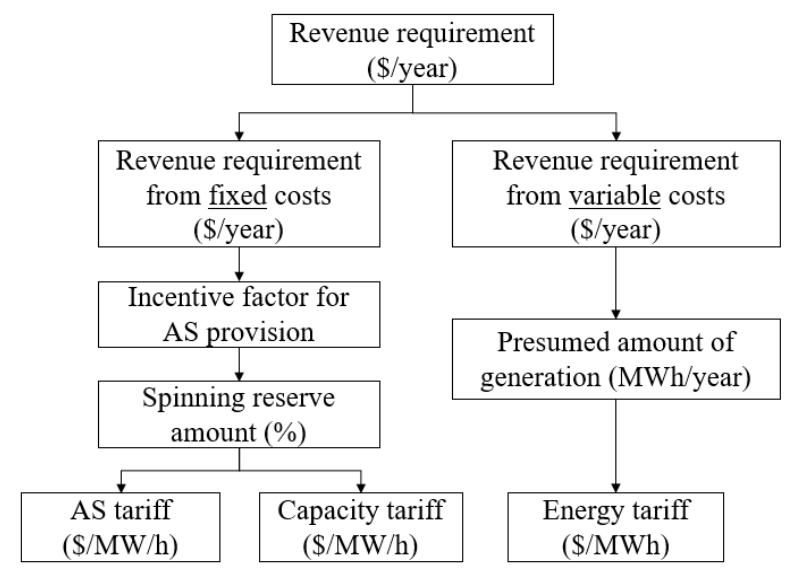

Fig.4. Spinning reserve concept in the proposed AS tariff mechanism

Seperating AS tariff from the existing UCT should be made in a way that the power plants, which are supposed to provide AS reserve (either FCR, FRR, or both), should be remunerated if and only if they allocate and activate the AS reserve as planned by the transmission system operator (TSO). In this 
respect, the following planning process by the TSO:

- TSO should determine total amount of AS reserve (MW) required for the grid in terms of FCR and FRR. To do so the common practice is to determine them on a monthly basis at the initial phase of the market opening.

- Total AS reserve should be allocated to power plants based on their availability and technical capability to provide AS according to the grid code of the country. This requires a prequalification and certification process [23].

Unified cost-based capacity tariffs are determined by the regulatory authority based on ARRs of the power plants. Fixed-costs include the costs associated with the provision of AS services. The power plants are remunarated for their available capacity through their UCTs, as described by (1):

$$
F C_{i}=\sum_{t=1}^{12}\left(U C T_{i} \times A V C_{i}^{t}\right)
$$

where,

$\begin{array}{ll}i & \text { Generator index } \\ t & \text { Month index } \\ F C_{i} & \text { Annual fixed cost of the generator i (\$/year) } \\ U C T_{i} & \text { Unified capacity tariff of generator i (\$/MW) } \\ A V C^{t_{i}} & \text { Average available capacity of generator i at month } \mathrm{t} \\ & \text { (A+B+C in Fig. 2) (MW) }\end{array}$

AS tariff of each power plant is separated from the UCT in a way that, if it provides AS reserves as allocated; then, the summation of the payments from AS tariff and recalculated capacity tariff should be equal to payment from the current UCT. Mathematically speaking:

$$
\begin{aligned}
& F C_{i}=\sum_{t=1}^{12}\left(C T_{i} \times A V C C_{i}^{t}+A S T_{i} \times A V C_{i}^{t}\right) \\
& A V C_{i}^{t}=A V C C_{i}^{t}+A S C_{i}^{t}
\end{aligned}
$$

where,

$C T_{i}$

Capacity tariff of generator $i$ for $A V C C{ }^{t}{ }_{i}$ after separation of AS tariff ( $\$ / \mathrm{MW})$

$A V C C^{t_{i}} \quad$ Average available capacity excluding AS reserve (C in

Fig. 2) (MW)

$A S T_{i} \quad$ Ancillary service tariff of generator $i(\$ / \mathrm{MW})$

$A S C{ }^{t_{i}}$

$$
\text { Average available AS capacity of generator } i \text { at month } t
$$$$
\text { (A + B in Fig. 2) (MW) }
$$

Constant $F C_{i}$ statisfies the second concern indicated above (i.e., increase of overall tariffs after separation of AS tariffs). Incentive factor, namely $K$, is for the second concern; to give incentives to those generators which are asked to provide more AS than planned, as illustrated in Fig. 5. The incentive factor $K$ represents the slope in Fig. 5 which can be calculated as:

$A S T_{i}=K \times C T_{i}$

If the slope is equal to one, total payment to generators is same as the case of UCT given by $C T_{i}=A S T_{i}$. Here, the higher slope results in a greater gap between the $A S T_{i}$ and $C T_{i}$. The difference between $A S T_{i}$ and $C T_{i}$ makes sense in terms of total payment to generators if they are asked to provide more AS than that of planned. In such a case, total payment to generators will increase. However if the power plant provides less than planned, asoociated income will reduce which is calulated by (5). The incentive factor should be negotiated and settled between the power plants and ISO. Recalculation of the capacity tariff after separation of AS tariff is presented by (6).

$$
\begin{aligned}
& F C_{i}=C T_{i} \times \sum_{t=1}^{12}\left(A V C C_{i}^{t}+K \times A S C_{i}^{t}\right) \\
& C T_{i}=\frac{F C_{i}}{\sum_{t=1}^{12}\left(A V C C_{i}^{t}+K \times A S C_{i}^{t}\right)}
\end{aligned}
$$

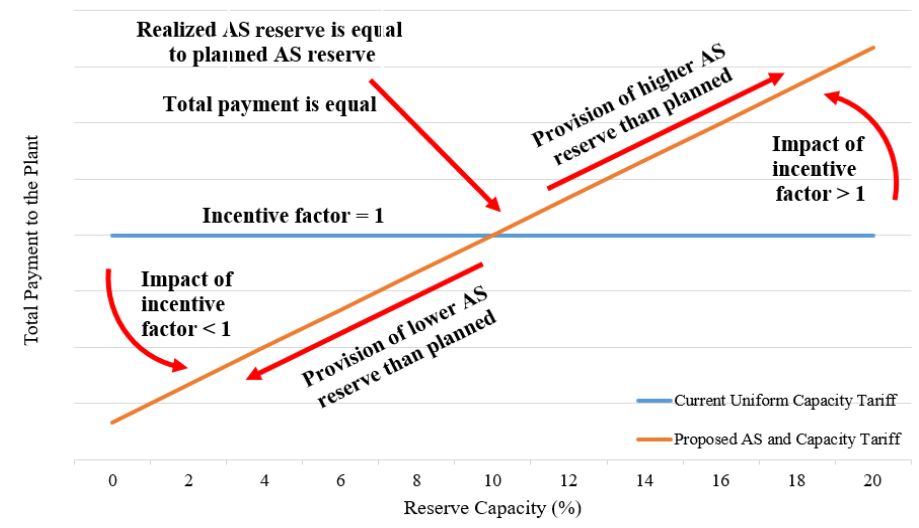

Fig. 5 Impact of incentive factor $K$ for $10 \%$ allocated capacity

\section{B. Eliciting AS Tariff from Unified Energy Tariff (UET)}

Eliciting AS tariff from UET ( $\$ / M W h)$ is investigated in this section. The proposed methodology for separation of AS tariff from UCT (Section II.A) is modified as illustrated in Fig. 6 . The methodology again starts by classifying fixed- and variable-costs of power plants and calculating fixed-cost based ARR of the power plants. However, since there is no capacity tariff, AST covers only fixed-costs which correspond to spinning reserves provision. The remaining fixed-costs should be converted to energy tariff as indicated in Fig. 6.

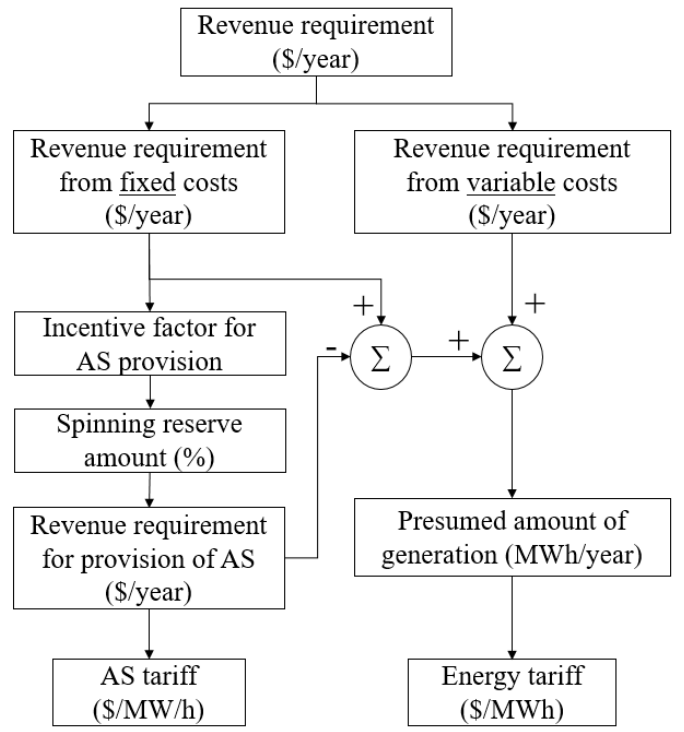

Fig.6. Flowchart of proposed methodology for eliciting AS tariff in case of UET 
Equations (7)-(9) express the calculation process of $U E T$, $A S T$, and re-calculation of energy tariff after separation $A S T$, respectively:

$$
\begin{aligned}
& U E T_{i}=\frac{F C_{i}+V C_{i}}{E_{i}} \\
& A S T_{i}=\frac{K \times F C_{i}}{E_{i} \times\left(1-A S R_{i}\right)+A S R_{i} \times K} \\
& E T_{i}=\frac{F C_{i}+V C_{i}-A S T_{i} \times E_{i} \times A S R}{E_{i}}
\end{aligned}
$$

where,

$V C_{i} \quad$ Annual variable cost of the generator $i$ (\$/year)

$E_{i} \quad$ Total amount of energy presumed to be produced by generator $i(\mathrm{MWh} /$ year $)$

$E T_{i} \quad$ Enery tariff of power plant $i$ (\$/MWh) after separation of $A S T$

To summarize the proposed approaches, Fig. 4 depicts the outline of the proposed approach for eliciting ancillary service from the tariff when unified capacity mechanism is applied. In the contrary, Fig. 6 represents eliciting ancillary service from the tariff when unified energy mechanism is applied. In brief, Fig 4 deals with capacity, however, Fig. 6 deals with energy.

\section{NUMERICAL INVESTIGATIONS AND DISCUSSIONS}

This section testifies effectiveness of the proposed method through numerical studies.

\section{A. Eliciting AS Tariff from UCT}

\section{1) Illustrative Example 1 - Calculation of UCT}

This example deals with calculation of $U C T, C T$, and AST for a generic thermal power plant for different values of incentive factor, $K$. Essentially, annual fixed costs of the power plant include those costs associated with the provision of AS services plus some profit to ensure that the power plants are satisfied with the tariffs. Table I and II represent the main parameters and fixed and variable costs of a generic thermal power plant. Note that profit ratio should be determined by the regulator. Here, profit ratio is assumed to be $10 \%$ and UCT is calculated as 3.52 $\$ / \mathrm{MW} / \mathrm{h}$ through (10):

$$
\begin{aligned}
U C T & =7,392,000.00(\$) / 300(M W) / 7,000(h) \\
& =3.52 \$ / M W / h
\end{aligned}
$$

TABLE I

MAIN PARAMETERS OF A GENERIC THERMAL POWER PLANT

\begin{tabular}{cc}
\hline Type of power plant & Thermal \\
\hline Plant capacity (MW) & 300 \\
Availability hours per year (8760 & 7,000 \\
maintenance hours) & 2,500 \\
Full load hours per year & $750,000(300 * 2,500)$ \\
Estimated energy (MWh/year) & 3,333 \\
Annual operation hours (capacity factor) & \\
\hline
\end{tabular}

\section{2) Illustrative Example 1 - Calculation of AS Tariff}

After calculating $U C T, A S$ tariff should be calculated. Given that the generic power plant is committed to provide $10 \%$ spinning reserve at real-time operation. $C T$ and $A C T$ are calculated using (1)-(6) for different incentive factors, $K$, as presented in Table III. For the calculations presented in Table III, it is assumed that the power plant allocates and activates $10 \%$ AS at the satisfactory level. Therefore, although total payment to the power plant from AS tariff increases along with incentive factor, total payment reamins fix (i.e., capacity payment plus AS payment). Such a behavior ensures the second concern in Fig. 1. Note that, capacity payment is significantly higher than that of AS in this example. The main reason is that $C T$ is subjected to $90 \%$ of the power plant capacity during available hours $(7,000 \mathrm{~h})$; wheras, $A C T$ is subjected to only $10 \%$ capacity of the power plant for operation hours $(3,333 \mathrm{~h})$, as presented in Table I.

TABLE II

FIXED AND VARIABLE COSTS OF A GENERIC POWER PLANT

\begin{tabular}{l|rr}
\hline \multicolumn{1}{c|}{ Cost item } & $\begin{array}{r}\text { Fixed Cost } \\
\text { (k\$/year) }\end{array}$ & $\begin{array}{c}\text { Variable } \\
\text { Cost } \\
\text { (k\$/year) }\end{array}$ \\
\hline Salary fund & $1,500.00$ & - \\
Depreciation / amortization of production & $1,750.00$ & - \\
facilities & 200.00 & - \\
Expense on basic and supporting materials & 800.00 & - \\
Cost of operational maintenance & - & $25,000.00$ \\
Fuel cost (natural gas, oil, coal, etc.) & - & 10.00 \\
Chemicals & - & 15.00 \\
Technical water consumption costs & 200.00 & - \\
Electricity utility and internal consumption & 10.00 & - \\
costs & 10.00 & - \\
Utility costs (except electricity) & 10.00 & - \\
Communication expenses & 5.00 & - \\
Office cost & 500.00 & - \\
Business trips & 50.00 & - \\
Advisory costs & 5.00 & - \\
Security costs & 400.00 & - \\
Rental costs & 70.00 & - \\
Insurance expense & 60.00 & - \\
Market operator service fee & 200.00 & - \\
Commission regulation fee & 50.00 & - \\
property tax & 100.00 & - \\
Property tax on land & 650.00 & - \\
Other operating costs & 150.00 & - \\
Interest rate cost & $\mathbf{6 , 7 2 0 . 0 0}$ & $\mathbf{2 5 , 0 2 5 . 0 0}$ \\
Other non-operational costs & $\mathbf{6 7 2 . 0 0}$ & $\mathbf{2 5 0 2 . 5 0}$ \\
\hline Total cost per year (k\$/year) & $\mathbf{7 , 3 9 2 . 0 0}$ & $\mathbf{2 7 , 5 2 7 . 5 0}$ \\
Profit (10\%) & & \\
Total cost for tariff calculation (k\$/year) & & - \\
\hline & & - \\
\hline
\end{tabular}

TABLE III

$C T$ AND ACT CALCULATIONS FOR DIFFERENT INCENTIVE FACTORS

\begin{tabular}{lrrr}
\hline Incentive factor $(\mathrm{K})$ & 1 & 2 & \multicolumn{1}{c}{4} \\
\hline $\begin{array}{l}\text { AS Reserve (Planned / } \\
\text { Provided) }\end{array}$ & $10 \% / 10 \%$ & $10 \% / 10 \%$ & $10 \% / 10 \%$ \\
$C T(\$ / \mathrm{MW} / \mathrm{h})$ & 3.52 & 3.36 & 3.08 \\
$A C \mathrm{~T}(\$ / \mathrm{MW} / \mathrm{h})$ & 3.52 & 6.72 & 12.32 \\
\hline $\begin{array}{l}\text { Capacity Payment } \\
\text { (k\$/year) }\end{array}$ & $\mathbf{7 , 0 4 0}$ & $\mathbf{6 , 7 2 0}$ & $\mathbf{6 , 1 6 0}$ \\
$\begin{array}{l}\text { AS Payment }(\mathbf{k} / \text { year) } \\
\text { Total Payment }\end{array}$ & $\mathbf{3 5 2}$ & $\mathbf{6 7 2}$ & $\mathbf{1 , 2 3 2}$ \\
(AS+Capacity) (k\$/year) & $\mathbf{7 , 3 9 2}$ & $\mathbf{7 , 3 9 2}$ & $\mathbf{7 , 3 9 2}$ \\
\hline
\end{tabular}


BALKAN JOURNAL OF ELECTRICAL \& COMPUTER ENGINEERING， Vol. 10, No. 1, January 2022

3) Illustrative Example 1 - Violating from scheduled amount of $A S$ at real-time operation

Assume that the power plant is planned to provide $10 \% \mathrm{AS}$ reserve; however, lower amount is realized in real-time operation. Consequently, associated revenue from AS tariff will considerably reduce. On the contrary, if asked to provide more than planned amount, associated revenue will increase with respect to the incentive factor, as presented in Table IV for the case of $K=2$.

TABLE IV

SCHEDULED VS PROVIDED $(\mathrm{K}=2)$

\begin{tabular}{|c|c|c|c|}
\hline Incentive factor (K) & 2 & 2 & 2 \\
\hline \multirow{2}{*}{ AS Reserve } & $\begin{array}{l}\text { Planned: } \\
10 \%\end{array}$ & $\begin{array}{l}\text { Planned: } \\
10 \%\end{array}$ & Planned: $10 \%$ \\
\hline & $\begin{array}{l}\text { Provided: } \\
10 \%\end{array}$ & $\begin{array}{l}\text { Provided: } \\
15 \%\end{array}$ & Provided: $\mathbf{5 \%}$ \\
\hline Capacity Tariff $(\$ / M W / h)$ & 3.36 & 3.36 & 3.36 \\
\hline $\begin{array}{l}\text { AS Capacity Tariff } \\
(\$ / \mathrm{MW} / \mathrm{h})\end{array}$ & 6.72 & 6.72 & 6.72 \\
\hline $\begin{array}{l}\text { Capacity Payment } \\
\text { (k\$/year) }\end{array}$ & 6,720 & 6,552 & 6,888 \\
\hline AS Payment (k\$year) & 672 & 1,008 & 336 \\
\hline $\begin{array}{l}\text { Total Payment } \\
\text { (AS+Capacity) } \\
\text { (k\$/year) }\end{array}$ & 7,392 & 7,560 & 7,224 \\
\hline
\end{tabular}

4) Illustrative Example 2 -More than one power plant contribute to AS

In a case that a power plant is planned for AS provision; however, couldn't realize associated commitment in real-time operation, TSO should attain the required reserve from other power plants. In this illustrative example, such a condition is investigated through two different cases. In Case 1, five generic power plants (see Fig. 7) are considered to provide satisfactory level of spinning reserves which are subjected to provide 5\% spinning reserve (Case 1). The scheduled and provided AS for these power plants are illustrated in Fig. 8. In Case 2, it is assumed that generic power plant B refuses to provide AS at a satisfactory level, and hence, generic power plant $\mathrm{F}$ is providing $5 \%$ more spinning reserve given that both plants have the same capacity as illustrated in Fig. 8 (Case 2). $U C T, C T$, and, AST of the power plants are presented in Fig. 7. Incentive factor, $K$, is assumed to be 2 .

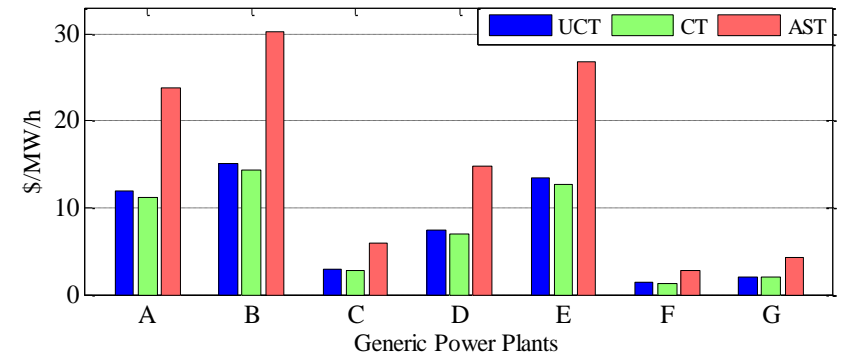

Fig.7. $U C T, C T$, and, $A S T$ of the generic power plants $(K=2)$

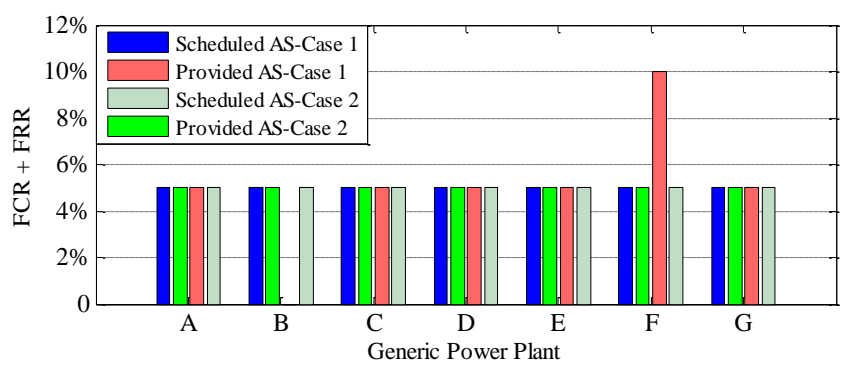

Fig.8. Scheduled versus provided AS reserve by the generic power plants (Cases 1 and 2)

Note that generic power plant $\mathrm{F}$ is selected to provide additional AS owing to low AST in comparison to the other power plants of this example. It is worth mentioning that tariffs of the power plants are disregarded while scheduling and allocating spinning reserve requirement among the power plants. Such an indicator could be considered; however, it might be out of scope of conducted study.

Annual payments to power plants for Case 1 and 2 are represented in Fig. 9 and Fig. 10, respectively. Total payment to power plant $\mathrm{B}$ reduces in Case 2 comparing to Case 1 as power plant $\mathrm{B}$ is excluded from $A S T$ payment. In Case 2, total payment to the plant $\mathrm{F}$ is more than that of Case 1 since the incentive factor greater than 1 , i.e. $\mathrm{K}=2$.

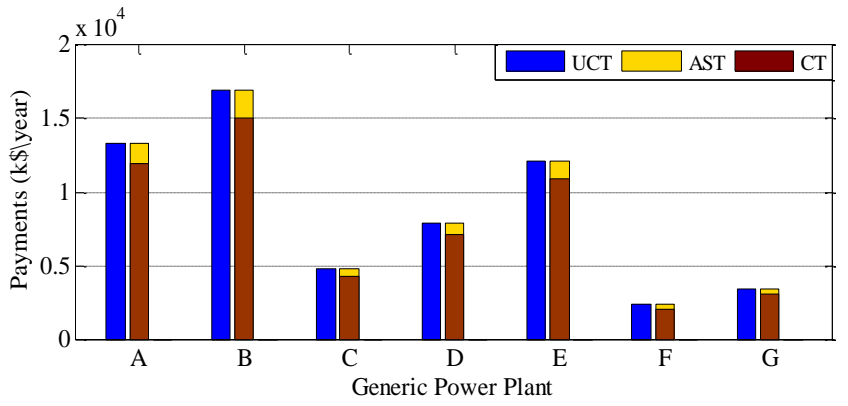

Fig.9. Annual revenue from $U C T, C T$, and, $A S T$ in Case 1

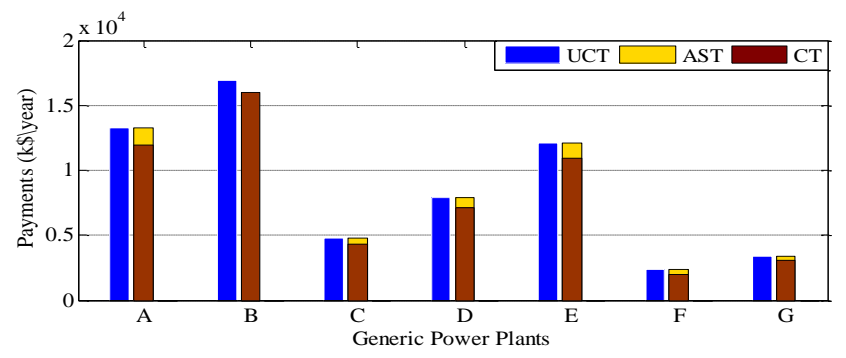

Fig.10. Annual revenue from $U C T, C T$, and, $A S T$ in Case 2

\section{B. Eliciting AS Tariff from UET}

In this example, the same condition as that of illustrative examples presented in Section III.A are considered; unless, the power plants are assumed to be subjected to UET. That is ARR of the power plant is remunarated through $U E T$. In this numerical example, $F C=27,528.00 \mathrm{k} \$ /$ year; $V C=7,392.00$ $\mathrm{k} \$ /$ year; $E=750,000 \mathrm{MWh} /$ year. UET of the generic power plant is $4.66 \$$-cent $/ \mathrm{kWh}$ which can be calculated as:

$U E T=\frac{27528+7392}{750000} \times 100=4.66 \$-\operatorname{cent} / \mathrm{kWh}$ 
BALKAN JOURNAL OF ELECTRICAL \& COMPUTER ENGINEERING, Vol. 10, No. 1, January 2022

$A S T$ of the power plant is $0.99 \$$-cent $/ \mathrm{kW} / \mathrm{h}(12)$ :

$$
A S T=\frac{K \times F C_{i}}{E_{i} \times\left(1-A S R_{i}\right)+A S R_{i} \times K}=0.99 \$-\text { cent } / \mathrm{kW} / \mathrm{h}
$$

where, $A S R$ is ancillary service in per units. Finally, energy tariff will be $4.56 \$$-cent $/ \mathrm{kWh}$ (13). As can be seen, after separation of $A S T, E T$ is lower than $U E T$ (i.e., $4.56<4.66$ ).

$$
E T_{i}=\frac{\left(F C_{i}+V C_{i}\right)-A S T_{i} \times E_{i} \times A S R_{i}}{E_{i}}=4.56 \$-\mathrm{cent} / \mathrm{kW} / \mathrm{h}
$$

\section{Calculation of Benefits of Countries from AS Coupling}

In this section, numerical analyses are performed to calculate benefits of two countries from coupling their AS and balancing mechanisms, based on the proposed cost-based AS tariffs eliciting approach. The following direct benefits are addressed:

- Common Dimensioning: It is an opportunity for TSOs to jointly dimensioning the total volume of balancing reserve, as illustrated in Fig. 11.

- Exchange of Reserve: It is the opportunity for TSOs to procure part of the balancing energy in another area (with no impact on the total amount of balancing reserve in the system) as illustrated in Fig. 11. The scenarios investigated here are summarized in Table V. In Fig. 11, three different conditions are depicted. First, each region holds spinning reserves based on their own need. In the common dimensioning, both side are holding 150 MW spining reserve as a common reserve. Finally, for exchanging reserve case, the $20 \mathrm{MW}$ reserve is exchanged between the regions.

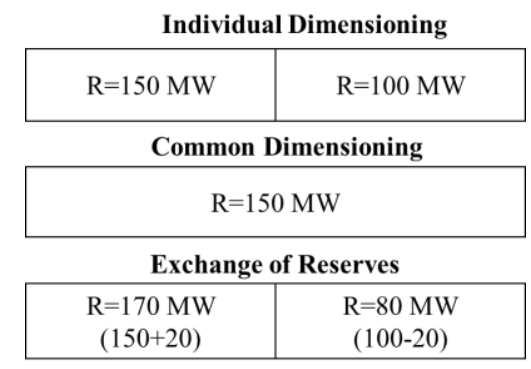

Fig.11. Direct benefits from coupling of AS (R: amount of allocated spinning reserve)

TABLE V

SCENARIOS INVESTIGATED IN SECTION III.C

\begin{tabular}{ccc}
\hline Scenario & Condition & $\begin{array}{c}\text { AS and Balancing } \\
\text { Coupling }\end{array}$ \\
\hline 1 & $\begin{array}{c}\text { No interconnection between } \\
\text { countries A and B } \\
\text { Interconnection between } \\
\text { country A and B }\end{array}$ & - \\
2 & $\begin{array}{c}\text { Common } \\
\text { dimensioning } \\
3\end{array}$ & country A and B \\
\end{tabular}

\section{1) Key Assumptions}

Given two interconnected countries, five power plants each with 100 MW capacity are assumed in both countries. Each power plant provides $20 \%$ spinning reserve, totally $100 \mathrm{MW}$, to compensate for loss of any power plant in the countries.
Available hours of the power plants are assumed to be $7,000 \mathrm{~h}$. The following annual parameters are assigned differently among the power plants to differentiate their cost-based tariffs: i) In-service hours, ii) Total fixed costs. More details of the assumptions are described in the Sections III.C.2, III.C.3, and III.C.4 on a country basis.

Parameters of the power plants and associated $C T$ and $A S T$ are provided in Tables VI and VII for Country A, and Tables VIII and IX for Country B, respectively. Incentive factor, $K$, is assumed to be 1.5 in all power plants. Additional cost of power plants due to provision of AS is assumed to be $10 \%$ of corresponding fixed costs.

TABLE VI

PARAMETERS OF THE POWER PLANTS - COUNTRY A

\begin{tabular}{l|ccccc}
\hline Parameter & G.A.1 & G.A.2 & G.A.3 & G.A.4 & G.A.5 \\
\hline Plant Capacity (MW) & 100 & 100 & 100 & 100 & 100 \\
Estimated Availability Hours (h) & 7,000 & 7,000 & 7,000 & 7,000 & 7,000 \\
In service hours along the year (h) & 3,300 & 6,000 & 5,000 & 3,000 & 5,000 \\
FC (k\$/year) & 2 & 2,500 & 3 & 2,500 & 3,500 \\
Additional costs related to AS (\%) & $10 \%$ & $10 \%$ & $10 \%$ & $10 \%$ & $10 \%$ \\
Profit (10\%) & $10 \%$ & $10 \%$ & $10 \%$ & $10 \%$ & $10 \%$ \\
Spinning reserve (\%) & $20 \%$ & $20 \%$ & $20 \%$ & $20 \%$ & $20 \%$ \\
ARR from CT and AST (k\$/year) & 2,420 & 3,025 & 3,630 & 3,025 & 4,235 \\
\hline
\end{tabular}

TABLE VII

TARIFF CALCULATIONS - COUNTRY A

\begin{tabular}{l|lllll}
\hline Parameter & G.A.1 & G.A.2 & G.A.3 & G.A.4 & G.A.5 \\
\hline$U C T(\$ / \mathrm{MW} / \mathrm{h})$ & 3.46 & 4.32 & 5.19 & 4.32 & 6.05 \\
$K$ & 1.5 & 1.5 & 1.5 & 1.5 & 1.5 \\
$C T(\$ / \mathrm{MW} / \mathrm{h})$ & 3.30 & 3.98 & 4.84 & 4.14 & 5.65 \\
$A S T(\$ / \mathrm{MW} / \mathrm{h})$ & 4.95 & 5.97 & 7.26 & 6.22 & 8.47 \\
\hline
\end{tabular}

TABLE VIII

PARAMETERS OF THE POWER PLANTS - COUNTRY B

\begin{tabular}{l|lllll}
\hline Parameter & G.B.1 & G.B.2 & G.B.3 & G.B.4 & G.B.5 \\
\hline Plant Capacity (MW) & 100 & 100 & 100 & 100 & 100 \\
Availability hours (h) & 7,000 & 7,000 & 7,000 & 7,000 & 7,000 \\
In service hours (h) & 3,300 & 6,000 & 5,000 & 3,000 & 5,000 \\
FC (\$year) & 1 & 1,250 & 1,500 & 1,250 & 1,750 \\
Additional costs related to AS (\%) & $10 \%$ & $10 \%$ & $10 \%$ & $10 \%$ & $10 \%$ \\
Profit (10\%) & $10 \%$ & $10 \%$ & $10 \%$ & $10 \%$ & $10 \%$ \\
Spinning reserve (\%) & $20 \%$ & $20 \%$ & $20 \%$ & $20 \%$ & $20 \%$ \\
ARR from CT and AST (k\$year) & 1,210 & 1,513 & 1,815 & 1,513 & 2,118 \\
\hline
\end{tabular}

TABLE IX

TARIFF CALCULATIONS - COUNTRY B

\begin{tabular}{l|lllll}
\hline Parameter & G.A.1 & G.A.2 & G.A.3 & G.A.4 & G.A.5 \\
\hline$U C T(\$ / M W / h)$ & 1.73 & 2.16 & 2.59 & 2.16 & 3.03 \\
$K$ & 1.5 & 1.5 & 1.5 & 1.5 & 1.5 \\
$C T(\$ / \mathrm{MW} / \mathrm{h})$ & 1.65 & 1.99 & 2.42 & 2.07 & 2.82 \\
$A S T(\$ / \mathrm{MW} / \mathrm{h})$ & 2.48 & 2.99 & 3.63 & 3.11 & 4.24 \\
\hline
\end{tabular}

$C T$ and $A S T$ of power plants in Country B are less than those of Country A as illustrated in Fig. 12. Difference is mainly due to fixed cost parameters of the power plants (see Table VI and Table VIII). 
values of ARRs to be recovered from $C T$ and $A S T$.

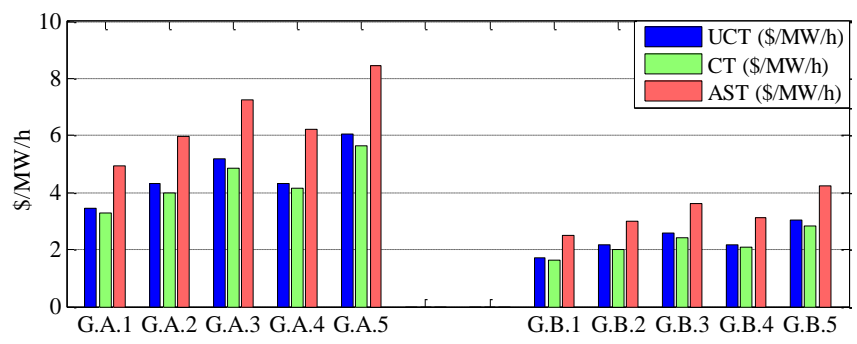

Fig.12. $C T$ and $A S T$ of power plants - Country A vs Country B

\section{2) Scenario 1 - No interconnection between Country A and Country $B$}

In case of no interconnection between the countries, the payments to power plants located at Countries A and B from $C T$ and AST are calculated as presented in Table $\mathrm{X}$ and Table $\mathrm{XI}$, respectively.

TABLE X CALCULATIONS OF PAYMENTS FOR CT AND AST - COUNTRY A

\begin{tabular}{l|ccccc}
\hline \multicolumn{1}{c|}{ Parameter } & G.A.1 & G.A.2 & G.A.3 & G.A.4 & G.A.5 \\
\hline $\begin{array}{l}\text { Capacity Payment from } \\
\text { CT (k\$year) }\end{array}$ & 2,093 & 2,308 & 2,904 & 2,652 & 3,388 \\
\hline $\begin{array}{l}\text { Total Payment from CT } \\
\text { (k\$/year) }\end{array}$ & \multicolumn{5}{|c}{13,346} \\
\hline $\begin{array}{l}\text { AS Payment from AST } \\
\text { k\$/year) }\end{array}$ & 326 & 716 & 726 & 372 & 847 \\
\hline $\begin{array}{l}\text { Total Payment from AST } \\
\text { (k\$year) }\end{array}$ & \multicolumn{5}{|c}{2,989} \\
\hline $\begin{array}{l}\text { Total Payment for CT and } \\
\text { AST (k\$/year) }\end{array}$ & 2,420 & 3,025 & 3,630 & 3,025 & 4,235 \\
\hline $\begin{array}{l}\text { Total Payment for CT and } \\
\text { AST (k\$/year) }\end{array}$ & & & 16,335 \\
\hline
\end{tabular}

TABLE XI

CALCULATIONS OF PAYMENTS FOR CT AND AST - COUNTRY B

\begin{tabular}{l|ccccc}
\hline \multicolumn{1}{c|}{ Parameter } & G.A.1 & G.A.2 & G.A.3 & G.A.4 & G.A.5 \\
\hline $\begin{array}{l}\text { Capacity Payment from } \\
\text { CT (k\$year) }\end{array}$ & 1,047 & 1,154 & 1,452 & 1,326 & 1,694 \\
\hline $\begin{array}{l}\text { Total Payment from CT } \\
\text { (k\$year) }\end{array}$ & \multicolumn{5}{|c}{6,673} \\
\hline $\begin{array}{l}\text { AS Payment from AST } \\
\text { (k\$year) }\end{array}$ & 163 & 358 & 363 & 186 & 423 \\
\hline $\begin{array}{l}\text { Total Payment from AST } \\
\text { (k\$year) }\end{array}$ & & & 1,495 & & \\
\hline $\begin{array}{l}\text { Total payment for CT and } \\
\text { AST (k\$year) }\end{array}$ & 1,210 & 1,512 & 1,815 & 1,512 & 2,117 \\
\hline $\begin{array}{l}\text { Total payment for CT and } \\
\text { AST (k\$/year) }\end{array}$ & & & 8,168 & & \\
\hline
\end{tabular}

\section{3) Scenario 2 - Common Dimensioning}

In this scenario, it is assumed that two countries are interconnected and they implement common dimensioning for their AS and balancing requirements. After common dimensioning, the amount of AS allocation in both countries reduces to $50 \mathrm{MW}$ representing total spinning reserve of 100 MW. Each country is assumed to reduce spinning reserve amounts from those power plants which have the highest AST. This reduction will occur in G.A.5, G.A.3, and G.A.2 in Country A, and G.B.5, G.B.3, and G.B.4 in Country B given their high relatively high $A S T$, as illustrated in Table XII and Table XIII, respectively. The tables also present recalculated
TABLE XII RECALCULATION OF PARAMETERS - COUNTRY A

\begin{tabular}{|c|c|c|c|c|c|c|}
\hline Parameter & $\begin{array}{c}\text { G.A.3 } \\
\text { (1) }\end{array}$ & $\begin{array}{c}\text { G.A.3 } \\
(2)\end{array}$ & $\begin{array}{c}\text { G.A.4 } \\
\text { (1) }\end{array}$ & $\begin{array}{c}\text { G.A.4 } \\
\text { (2) }\end{array}$ & $\begin{array}{c}\text { G.A.5 } \\
\text { (1) }\end{array}$ & $\begin{array}{c}\text { G.A.5 } \\
(2)\end{array}$ \\
\hline $\begin{array}{l}\text { Plant capacity (mw) } \\
\text { Estimated }\end{array}$ & 100 & 100 & 100 & 100 & 100 & 100 \\
\hline $\begin{array}{l}\text { Availability Hours } \\
\text { per year (h) }\end{array}$ & 7,000 & 7,000 & 7,000 & 7,000 & 7,000 & 7,000 \\
\hline $\begin{array}{l}\text { In service hours } \\
\text { along the year }(\mathrm{h})\end{array}$ & 5,000 & 5,000 & 3,000 & 3,000 & 5,000 & 5,000 \\
\hline $\begin{array}{l}\text { Total cost for } \mathrm{CT} \\
\text { calculation } \\
\text { (k\$/year) }\end{array}$ & 3,000 & 3,000 & 2,500 & 2,500 & 3,500 & 3,500 \\
\hline $\begin{array}{l}\text { Costs related to AS } \\
\text { provision }(\%)\end{array}$ & $10 \%$ & $0 \%$ & $10 \%$ & $10 \%$ & $10 \%$ & $0 \%$ \\
\hline $\begin{array}{l}\text { Costs related to AS } \\
\text { provision ( } \mathrm{k} \$ / \text { year })\end{array}$ & 300 & - & 250 & 250 & 350 & - \\
\hline Profit $(10 \%)$ & $10 \%$ & $10 \%$ & $10 \%$ & $10 \%$ & $10 \%$ & $10 \%$ \\
\hline $\begin{array}{l}\text { Spinning reserve } \\
(\%)\end{array}$ & $20 \%$ & $0 \%$ & $20 \%$ & $10 \%$ & $20 \%$ & $0 \%$ \\
\hline $\begin{array}{l}\text { Total spinning } \\
\text { reserve amount } \\
\text { (MW) }\end{array}$ & 20 & - & 20 & 10 & 20 & - \\
\hline $\begin{array}{l}\text { ARR from } \mathrm{CT} \text { and } \\
\text { AST per year } \\
(\mathrm{k} \$ / \text { year) }\end{array}$ & 3,630 & 3,300 & 3,025 & 3,025 & 4,235 & 3,850 \\
\hline
\end{tabular}

TABLE XIII

RECALCULATION OF PARAMETERS - COUNTRY A

\begin{tabular}{|c|c|c|c|c|c|c|}
\hline Parameter & $\begin{array}{c}\text { G.A.3 } \\
\text { (1) }\end{array}$ & $\begin{array}{l}\text { G.A.3 } \\
(2)\end{array}$ & $\begin{array}{c}\text { G.A.4 } \\
\text { (1) }\end{array}$ & $\begin{array}{l}\text { G.A.4 } \\
\text { (2) }\end{array}$ & $\begin{array}{l}\text { G.A.5 } \\
\text { (1) }\end{array}$ & $\begin{array}{c}\text { G.A.5 } \\
(2)\end{array}$ \\
\hline Plant capacity (mw) & 100 & 100 & 100 & 100 & 100 & 100 \\
\hline $\begin{array}{l}\text { Estimated } \\
\text { Availability Hours } \\
\text { per year (h) }\end{array}$ & 7,000 & 7,000 & 7,000 & 7,000 & 7,000 & 7,000 \\
\hline $\begin{array}{l}\text { In service hours } \\
\text { along the year (h) }\end{array}$ & 5,000 & 5,000 & 3,000 & 3,000 & 5,000 & 5,000 \\
\hline $\begin{array}{l}\text { Total cost for } \mathrm{CT} \\
\text { calculation } \\
\text { (k\$/year) }\end{array}$ & 1,500 & 1,500 & 1,250 & 1,250 & 1,750 & 1,750 \\
\hline $\begin{array}{l}\text { Costs related to AS } \\
\text { provision }(\%)\end{array}$ & $10 \%$ & - & $10 \%$ & $10 \%$ & $10 \%$ & - \\
\hline $\begin{array}{l}\text { Costs related to AS } \\
\text { provision }(\mathrm{k} \$ / \text { year) }\end{array}$ & 150 & - & 125 & 125 & 175 & - \\
\hline Profit $(10 \%)$ & $10 \%$ & $10 \%$ & $10 \%$ & $10 \%$ & $10 \%$ & $10 \%$ \\
\hline $\begin{array}{l}\text { Spinning reserve } \\
(\%)\end{array}$ & $20 \%$ & $0 \%$ & $20 \%$ & $10 \%$ & $20 \%$ & $0 \%$ \\
\hline $\begin{array}{l}\text { Total spinning } \\
\text { reserve amount } \\
(\mathrm{MW})\end{array}$ & 20 & - & 20 & 10 & 20 & - \\
\hline $\begin{array}{l}\text { ARR from CT and } \\
\text { AST per year } \\
(\mathrm{k} \$ \text { /year) }\end{array}$ & 1,815 & 1,650 & 1,513 & 1,513 & 2,118 & 1,925 \\
\hline
\end{tabular}

Since G.A.3, G.A.5, G.B.3, and G.B.5 are not providing AS, their total annual fixed cost reduces since AS provision payment is excluded. This reduction will essentially reduce their $C T$ s, as illustrated in Fig. 13. Note that, although these power plants will not provide AS, their capacity connected with AS in Scenario 1 should be still be remunerated through the $C T$ in Case 2. That is, total capacity subjected to $C T$ in Case 2 increases if compared to Case 1 by the amount of spinning reserve allocated in Case 1, as illustrated in Fig. 14. Nevertheless, total payments of country A and B for $C T$ and $A S T$ reduces as presented in Fig. 15. This result shows that total savings of Countries $\mathrm{A}$ and $\mathrm{B}$ from common dimensioning is $1,073 \mathrm{k} \$$ year for this particular generic example. Note that ARRs of G.A.4 and G.B.4 from $C T$ and 
AST remained fixed given the assumption that costs related to AS provision do not change along with reduction of AS amount from $20 \%$ to $10 \%$.

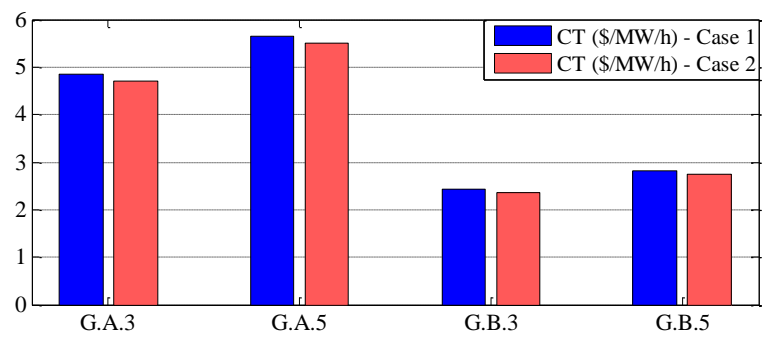

Fig.13. $C T$ of G.A.3, G.A.5, G.B.3, and G.B.5 (Case 1 vs Case 2)

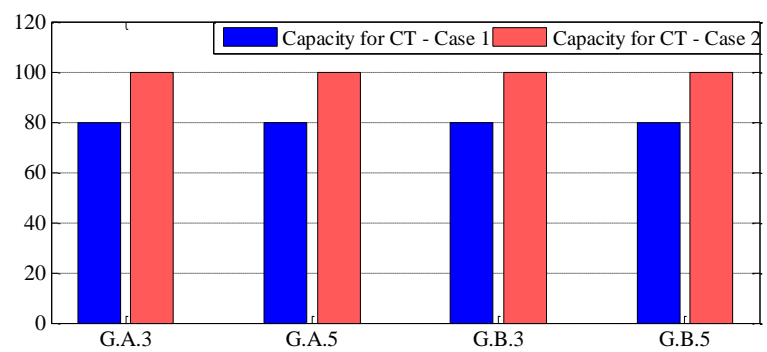

Fig.14. Capacity of G.A.3, G.A.5, G.B.3, and G.B.5 subjected to $C T$ (Case 1 vs Case 2)

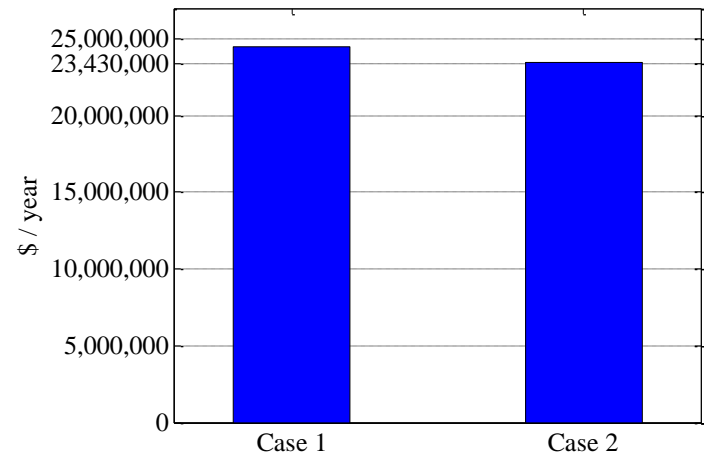

Fig.15. Total payment for $C T$ and $A S T$ (Country A + Country B)

\section{4) Scenario 3 - Exchange of $A S$}

In this scenario, it is assumed that Countries A and B are exchanging $20 \mathrm{MW}$ spinning reserve. The exchange is between G.A.1 and G.B.1. That is, G.A.1 is not providing any spinning reserve while G.B.1 is providing additional $20 \mathrm{MW}$ to compensate for. This exchange still ensures $100 \mathrm{MW}$ total spinning reserve in total (i.e., Country A plus Country B). Recalculated values of ARRs, tariffs, and payments are provided in Table XIV-Table XVI for Country A, and Table XVIITable XIX for Country B, respectively.

Benefits of the countries from AS and coupling mechanisms are presented in Fig. 16. One can argue that the benefit is not observable and relatively small. However in the numerical analysis, normalized fixed costs $(\$ / \mathrm{MW})$ of the power plants are assumed almost similar in order to be realistic (fixed cost range is taken from the literature [19], [21]. In addition, profit component of the power plants (10\%) and incentive factor $(K=1.5)$ are assumed to be same. Such parameters can result in higher benefits than calculated in the generic numerical examples. Nevertheless, main focus is given in the study to propose an AS tariff separation methodology which satisfies the main concerns mentioned above.

TABLE XIV

RECALCULATION OF PARAMETERS - COUNTRY A

\begin{tabular}{|c|c|c|c|c|c|}
\hline Parameter & G.A.1 & G.A.2 & G.A.3 & G.A.4 & G.A.5 \\
\hline Plant Capacity (MW) & 100 & 100 & 100 & 100 & 100 \\
\hline $\begin{array}{l}\text { Estimated Availability } \\
\text { Hours per year }(\mathrm{h})\end{array}$ & 7,000 & 7,000 & 7,000 & 7,000 & 7,000 \\
\hline $\begin{array}{l}\text { In service hours along the } \\
\text { year }(h)\end{array}$ & 3,300 & 6,000 & 5,000 & 3,000 & 5,000 \\
\hline $\begin{array}{l}\text { Total cost for CT calculation } \\
\text { (\$/year) }\end{array}$ & 2,000 & 2,500 & 3,000 & 2,500 & 3,500 \\
\hline $\begin{array}{l}\text { Costs related to AS } \\
\text { provision }(\%)\end{array}$ & - & $10 \%$ & - & $10 \%$ & - \\
\hline $\begin{array}{l}\text { Costs related to AS } \\
\text { provision (\$/year) }\end{array}$ & - & 250 & - & 250 & - \\
\hline Profit $(10 \%)$ & $10 \%$ & $10 \%$ & $10 \%$ & $10 \%$ & $10 \%$ \\
\hline Spinning reserve (\%) & - & $20 \%$ & - & $10 \%$ & - \\
\hline $\begin{array}{l}\text { Total spinning reserve } \\
\text { amount (MW) }\end{array}$ & - & 20 & - & 10 & - \\
\hline $\begin{array}{l}\text { ARR from CT and AST per } \\
\text { year (\$/year) }\end{array}$ & 2,200 & 3,025 & 3,300 & 3,025 & 3,850 \\
\hline
\end{tabular}

TABLE XV

RECALCULATION OF CT AND AST - COUNTRY A

\begin{tabular}{l|lllll}
\hline Parameter & G.A.1 & G.A.2 & G.A.3 & G.A.4 & G.A.5 \\
\hline CT $(\$ / M W / h)$ & 3.14 & 3.98 & 4.71 & 4.23 & 5.50 \\
AST $(\$ / M W / h)$ & - & 5.97 & - & 6.35 & - \\
\hline
\end{tabular}

TABLE XVI

RECALCULATION OF PAYMENT - COUNTRY A

\begin{tabular}{l|ccccc}
\hline \multicolumn{1}{c|}{ Parameter } & G.A.1 & G.A.2 & G.A.3 & G.A.4 & G.A.5 \\
\hline $\begin{array}{l}\text { Capacity Payment from } \\
\text { CT (k\$year) }\end{array}$ & 2,200 & 2,309 & 3,300 & 2,835 & 3,850 \\
\hline $\begin{array}{l}\text { Total Payment from CT } \\
\text { (k\$year) }\end{array}$ & \multicolumn{5}{|c}{14,493} \\
\hline $\begin{array}{l}\text { AS Payment from AST } \\
\text { (k\$/year) }\end{array}$ & - & 716 & - & 190 & - \\
\hline $\begin{array}{l}\text { Total Payment from } \\
\text { AST (k\$/year) }\end{array}$ & \multicolumn{5}{|c}{907} \\
\hline $\begin{array}{l}\text { Total Payment for CT } \\
\text { and AST (k\$year) }\end{array}$ & 2,200 & 3,025 & 3,300 & 3,025 & 3,850 \\
\hline
\end{tabular}

\begin{tabular}{l|l}
\hline $\begin{array}{l}\text { Total Payment for CT } \\
\text { and AST (k\$/year) }\end{array}$ & 15,400 \\
\hline
\end{tabular}

TABLE XVII

RECALCULATION OF PARAMETERS - COUNTRY B

\begin{tabular}{|c|c|c|c|c|c|}
\hline Parameter & G.A.1 & G.A.2 & G.A.3 & G.A.4 & G.A.5 \\
\hline Plant Capacity (MW) & 100 & 100 & 100 & 100 & 100 \\
\hline $\begin{array}{l}\text { Estimated Availability } \\
\text { Hours per year }(\mathrm{h})\end{array}$ & 7,000 & 7,000 & 7,000 & 7,000 & 7,000 \\
\hline $\begin{array}{l}\text { In service hours along the } \\
\text { year }(\mathrm{h})\end{array}$ & 3,300 & 6,000 & 5,000 & 3,000 & 5,000 \\
\hline $\begin{array}{l}\text { Total cost for CT calculation } \\
\text { (\$/year) }\end{array}$ & 1,000 & 1,250 & 1,500 & 1,250 & 1,750 \\
\hline $\begin{array}{l}\text { Costs related to AS } \\
\text { provision }(\%)\end{array}$ & $10 \%$ & $10 \%$ & - & $10 \%$ & - \\
\hline $\begin{array}{l}\text { Costs related to AS } \\
\text { provision (\$/year) }\end{array}$ & $10 \%$ & $10 \%$ & $10 \%$ & $10 \%$ & $10 \%$ \\
\hline Profit $(10 \%)$ & $20 \%$ & $20 \%$ & - & $10 \%$ & - \\
\hline Spinning reserve (\%) & 1,210 & 1,513 & 1,650 & 1,513 & 1,925 \\
\hline $\begin{array}{l}\text { Total spinning reserve } \\
\text { amount (MW) }\end{array}$ & 100 & 100 & 100 & 100 & 100 \\
\hline $\begin{array}{l}\text { ARR from CT and AST per } \\
\text { year (\$/year) }\end{array}$ & 7,000 & 7,000 & 7,000 & 7,000 & 7,000 \\
\hline
\end{tabular}


TABLE XVIII

RECALCULATION OF CT AND AST - COUNTRY B

\begin{tabular}{l|lllll}
\hline Parameter & G.A.1 & G.A.2 & G.A.3 & G.A.4 & G.A.5 \\
\hline CT $(\$ / \mathrm{MW} / \mathrm{h})$ & 1.65 & 1.99 & 2.36 & 2.12 & 2.75 \\
AST $(\$ / \mathrm{MW} / \mathrm{h})$ & 2.48 & 2.99 & - & 3.17 & - \\
\hline
\end{tabular}

TABLE XIX

RECALCULATION OF PAYMENT - COUNTRY B

\begin{tabular}{l|ccccc}
\hline \multicolumn{1}{c|}{ Parameter } & G.A.1 & G.A.2 & G.A.3 & G.A.4 & G.A.5 \\
\hline $\begin{array}{l}\text { Capacity Payment from } \\
\text { CT (k\$/year) }\end{array}$ & 938 & 1,154 & 1,650 & 1,417 & 1,925 \\
\hline $\begin{array}{l}\text { Total Payment from CT } \\
\text { (k\$/year) }\end{array}$ & \multicolumn{5}{c}{7,084} \\
\hline $\begin{array}{l}\text { AS Payment from AST } \\
\text { (k\$year) }\end{array}$ & 229 & 358 & - & 95 & - \\
\hline $\begin{array}{l}\text { Total Payment from } \\
\text { AST (k\$year) }\end{array}$ & & & $682,840.28$ & \\
\hline $\begin{array}{l}\text { Total Payment for CT } \\
\text { and AST (k\$year) }\end{array}$ & 1,167 & 1,513 & 1,650 & 1,513 & 1,925 \\
\hline $\begin{array}{l}\text { Total Payment for CT } \\
\text { and AST (k\$year) }\end{array}$ & \multicolumn{5}{|c}{7,767} \\
\hline
\end{tabular}

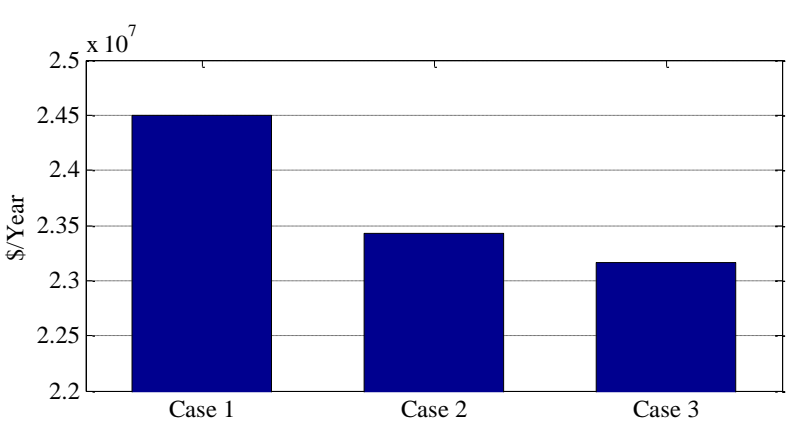

Fig.16. Total payment for $C T$ and $A S T$ (Country A + Country B)

\section{DISCUSSIONS AND CONCLUSIONS}

This study dealt with eliciting AS tariffs from unified capacity and energy tariffs through a cost-based approach. In the proposed framework, maintaining annual revenue requirements of the power plants are considered as the main objective while separating the AS tariff from unified tariffs. The conducted study addressed the following challenges: 1) incentivizinglpenalizing AS provision morelless than scheduled amount which is tackled through an incentive factor, and 2) preventing overall tariff increment (customer tariff) after eliciting AS tariff which is addressed by applying fixing constraint to the overall tariff at before and after AS tariff eliciting conditions. Main concern of power plants in providing AS is the additional costs connected with providing active power regulation and loss of opportunity due to allocation of some reserves of AS provision. On the other hand, main concern of transmission system operator and electricity market regulatory authorities is remunerating the power plants which do not provide AS, through unified tariffs. Numerical case studies demonstrated that the proposed approach satisfies such concerns. In addition, electricity market regulatory authorities of the countries, which implement unified capacity and/or energy tariffs, can consider the proposed tariff separation approach for determining true cost level of their country in procuring AS. Therefore, such countries do not need to wait until market opening to start benefitting from AS coupling with neighbour countries. The proposed approach enables them to quantify their benefits.

\section{ACKNOWLEDGMENT}

This paper presents the scientific results of the transnational project "Multi-layer aggregator solutions to facilitate optimum demand response and grid flexibility" (SMART-MLA Project No: 89029 ), co-financed by TÜBİTAK (Turkey), SWEA (Sweden), EUDP (Denmark), UEFISCDI (Romania), and RCN (Norway) under ERA-Net Smart Energy Systems, SG+ 2017 Program. The study is supported by "TÜBITTAK TEYDEB 1509 - Uluslararası Sanayi Ar-Ge Projeleri” program with the project number of 9180003 .

\section{REFERENCES}

[1] Y. G. Rebours, D. S. Kirschen, M. Trotignon, and S. Rossignol, "A survey of frequency and voltage control ancillary services-Part I: Technical features," IEEE Trans. Power Syst., vol. 22, no. 1, pp. 350-357, 2007.

[2] N. A. El-Taweel, H. Khani, and H. E. Z. Farag, "Optimal Sizing and Scheduling of LOHC-Based Generation and Storage Plants for Concurrent Services to Transportation Sector and Ancillary Services Market," IEEE Transactions on Sustainable Energy, vol. 11, pp. 1381-1393, 2020.

[3] D. Jay and S. S. K, "Game Theoretical Approach to Novel Reactive Power Ancillary Service Market Mechanism," IEEE Transactions on Power Systems, pp. 1-1, 2020.

[4] A. Zobian and M. D. Ilic, "Unbundling of transmission and ancillary services. I. Technical issues," IEEE Trans. Power Syst., vol. 12, no. 2, pp. 539-548, 1997.

[5] M. Vanouni and N. Lu, "A Reward Allocation Mechanism for Thermostatically Controlled Loads Participating in Intra-Hour Ancillary Services," IEEE Transactions on Smart Grid, vol. 9, pp. 4209-4219, 2018.

[6] G. D. Zotti, S. A. Pourmousavi, H. Madsen, and N. K. Poulsen, "Ancillary Services 4.0: A Top-to-Bottom Control-Based Approach for Solving Ancillary Services Problems in Smart Grids," IEEE Access, vol. 6, pp. 11694-11706, 2018.

[7] Y. G. Rebours, D. S. Kirschen, M. Trotignon, and S. Rossignol, "A survey of frequency and voltage control ancillary services-Part II: Economic features," IEEE Trans. Power Syst., vol. 22, no. 1, pp. 358-366, 2007.

[8] L. Meeus, K. Purchala, and R. Belmans, "Development of the internal electricity market in Europe," The Electricity Journal, vol. 18 , no. 6, pp. 25-35, 2005.

[9] K. Bhattacharya and J. Zhong, "Reactive power as an ancillary service," IEEE Trans. Power Syst., vol. 16, 2, pp. 294-300, 2001.

[10] R. Raineri, S. Rios, and D. Schiele, "Technical and economic aspects of ancillary services markets in the electric power industry: an international comparison," Energy policy, vol. 34, no. 13, pp. 1540-1555, 2006.

[11] O. B. Tör, M.E. Cebeci, M. Stojkovic, D. Orlic, C. Godfrey, G. Wray, et al., "Sub-Regional Direct Benefits from Cross-Border Provision of Balancing Energy and Reserves at Black Sea Region Based on Market-Based and Cost-Based Approaches," presented at the CIGRE RSEEC October 2018.

[12] E. Ela, A. Tuohy, M. Milligan, B. Kirby, and D. Brooks, "Alternative approaches for incentivizing the frequency responsive reserve ancillary service," The Electricity Journal, vol. 25, no. 4, pp. 88-102, 2012. 
[13] H. Singh and A. Papalexopoulos, "Competitive procurement of ancillary services by an independent system operator," IEEE Trans. Power Syst., vol. 14, no. 2, pp. 498-504, 1999.

[14] M. B. Zammit, D. J. Hill, and R. J. Kaye, "Designing ancillary services markets for power system security," IEEE Trans. Power Syst., vol. 15, no. 2, pp. 675-680, 2000.

[15] I. De la Fuente, D. Soler, G. Relaño, O. Largo, T. Gómez, R. Martínez, et al., "F. Remuneration Framework and Cost Allocation Methodology for AGC Ancillary Services Markets," in Power System Computation Conference PSCC, 1999.

[16] A. Zobian and M. D. Ilic, "Unbundling of transmission and ancillary services. II. Cost-based pricing framework," IEEE Trans. Power Syst., vol. 12, no. 2, pp. 549-558, 1997.

[17] S. F. Tierney, T. Schatzki, and R. Mukerji, "Uniform-pricing versus pay-as-bid in wholesale electricity markets: does it make a difference?," New York ISO, 2008.

[18] J. E. Bowring, "The evolution of PJM's capacity market," in Competitive Electricity Markets, ed: Elsevier, 2008, pp. 363386.

[19] U. EIA, "Capital cost estimates for utility scale electricity generating plants," US Department of Energy, Energy Information Administration. Parts on PHP and batteries http://www. gov/analysis/studies/powerplants/capitalcost/pdf/capcost_assu mption. pdf, 2016.

[20] M. Scherer, M. Zima, and G. Andersson, "An integrated panEuropean ancillary services market for frequency control," Energy policy, vol. 62, pp. 292-300, 2013.

[21] R. Tidball, J. Bluestein, N. Rodriguez, and S. Knoke, "Cost and performance assumptions for modeling electricity generation technologies," National Renewable Energy Lab.(NREL), Golden, CO (United States)2010.

[22] E. N. o. T. S. Operators, "Network Code on Load-Frequency Control and Reserves 6," 2013.

[23] B. Kirby, "Ancillary services: Technical and commercial insights," Retrieved October, vol. 4, p. 2012, 2007.

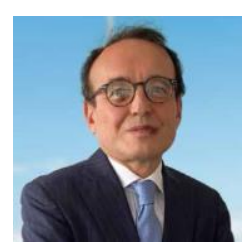

\section{BIOGRAPHIES}

Hikmet Sezer received his BS degree from Middle East Technical University (METU), Turkey, in 1991. He is working as Chairman of the Board at Yeşilırmak Elektrik Dağıtım A.Ş.., İstanbul, Turkey.

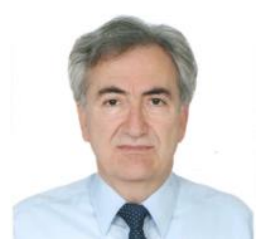

Ali Nezih Güven received the B.S. degree from Middle East Technical University (METU), in 1979 and the M.S. and Ph.D. degrees from the Ohio State University, USA in 1981 and 1984, respectively. He is currently a professor in the Department of Electrical and Electronics Engineering at METU, Ankara, Turkey. His research interests are the analysis, design, and operation of power systems, and distribution automation.

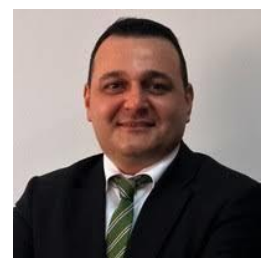

Osman Bülent Tör received his B.S., M.S. and Ph.D. degrees from Middle East Technical University (METU), Turkey, in 1998, 2001 and 2008, respectively. He is working as managing partner and director at EPRA Electric Energy Co., Ankara, Turkey.

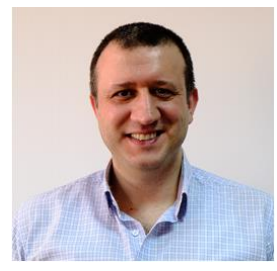

Mahmut Erkut Cebeci received his B.S. and M.S. degrees from Middle East Technical University (METU), Ankara, Turkey, in 2005 and 2008, respectively. $\mathrm{He}$ is working as managing partner and director at EPRA Electric Energy Co., Ankara, Turkey.

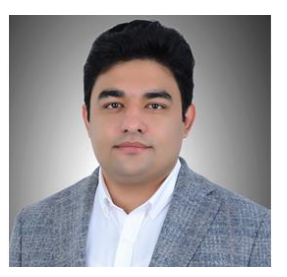

Saeed Teimourzadeh received the Ph.D. degree in power electrical engineering from School of Electrical and Computer Engineering, University of Tehran, Tehran, Iran, in 2018. From 2016 to 2017, he was a Research Associate with the Electrical and Computer Engineering Department at the Illinois Institute of Technology (IIT), Chicago, IL, USA. He is currently R\&D Director with EPRA Electric Energy Co., Ankara, Turkey. Dr. Teimourzadeh served the Journal of Modern Power Systems and Clean Energy (MPCE) as the editor and received the 2018 excellence in reviewing award from MPCE Journal. His research interests include microgrid protection, control and stability, and smart grid initiatives. 